\title{
The Existence of Indonesian Language: Pidgin or Creole
}

\author{
Dellis Pratika \\ dellispratika@gmail.com \\ State Islamic Institute of Palangka Raya \\ Jl. G. Obos Komplek Islamic Centre Palangka Raya, Kalimantan Tengah, Indonesia
}

Received: August 2, 2016; Accepted: September 9, 2016; Published: September 27, 2016

\begin{abstract}
Indonesian language or sometimes called Bahasa is the national language of Indonesia. It was derived from Malay language and established as a national language in 1928. Until now, the Indonesian language keeps borrowing words from other languages. It was questioned whether the language was actually a pidgin that authorized into a creole since it was not only contained of Malay language but also languages that it was made contact with since colonialism eras, such as Dutch, English, Arabic, and other languages. This research used library study to find the data since it was not possible to trace the data in the field. This study was aimed to determine whether the Indonesian language was categorized into pidgin or creole. The result of the study revealed that Indonesian was not either pidgin or creole since the characteristics features did not meet any of them. It is believed that the Indonesian language was one of the means to achieve independence, but it is opened to receive lexicons from other foreign languages as the words keep increasing each year that can be seen in Kamus Besar Bahasa Indonesia (KBBI).
\end{abstract}

Keywords: Indonesian language, Malay language, Pidgin, Creole

How to cite this paper: Pratika, D. (2016). The Existence of Indonesian Language: Pidgin or Creole. Journal on English as a Foreign Language, 6(2), 83-100.

Indonesia is an archipelago that has many ethnic languages spread from Sabang to Merauke. However, none of the ethnic languages becomes the official language. The country uses the Indonesian language instead. It is believed that Indonesian is one of the Malay dialects before it becomes a national language in 
1928. Collins (2005, p. 88) says that since 1928, the Indonesian language has already been spread and known as the national and official language of Indonesia. Furthermore, it is not called Malay language anymore.

Collins (1986, p. 4) also states in his other book about Ambon creolization,

By this time Malay had become a symbol for Indonesian nationalists, a symbol of their unity and nationhood. Private schools using as the medium of instruction sprang up throughout Java and Sumatra. The demonstration occurred protesting Dutch efforts to change the medium in the government schools from Malay to the local languages. In 1928 the young nationalists declared Indonesian (Malay) the national language. A new magazine, Pudjangga Baru, was first published to stimulate the growth of Indonesian (Malay).

It clearly showed that Malay was the Indonesian language as stated twice in parentheses by Collins. Indonesian scholars before the Sumpah Pemuda learned the Dutch language at school. In 1928, Indonesian language increased its prestige and attempted to change the introduction language at school, even though they just started in Java and Sumatra first because most of the schools in Indonesia were first established on those islands. It also needed to be noticed that media had a role in promoting the Indonesian language. Besides Pudjangga Baru, there was also a publisher which accommodated Indonesian writers, who were mostly from Sumatra. It was well-known with the name Balai Pustaka and it published many famous Indonesian literature works, such as Siti Nurbaya, Salah Pilih, Salah Asuhan, and so on.

The development of Malay language was divided into 3 phases, prehistoric, ancient, and modern. Before discussing the Indonesian language, it is better to trail its origin, prehistoric Malay language, which became the forerunner of the Indonesian language that is now used by the Indonesian as the official language, the standard language, the national language, and also lingua franca in Indonesia. The Malay language was derived from Austronesian language family. Collins (2005, p. 1) says that the ancient Austronesian languages are formed from the East Asia which is known nowadays as Taiwan at about 10.000 years ago.

He also mentions that the island which became the origin of Austronesian languages was the island called Formosa. From this island, the Austronesian then migrate to the south, the west, and the east. In the southern regions, they migrated through the area that is now called the Philippines and further to the west they resided in the 10.000 islands of Southeast Asia. Toward the east, they built new cultures in the new islands which had never populated by human that were scattered in the Pacific Islands. Austronesian languages 
consisted of 1.000 languages which were used from the coast of Africa in Madagascar to the islands in the United States of America, in Rapanui (Easter Island, Chile), and from the mountains of Taiwan to the snowy volcanic peaks in New Zealand.

Actually, Malay language's was first known in the $8^{\text {th }}$ century. It was found in Sumatra that there had been an ancient text written in the Malay language (628 CE) although it still adopted Indian's orthography. This was the beginning of ancient Malay according to Collins $(2005$, p. 8) and it lasted for hundred years, approximately in the $16^{\text {th }}$ century and this century indicated the end of a long ancient phase of Malay language history (Collins, 2005, p. 27). In the same century, the Malay language also started to renew and determine its identity. It was called the transition phase from ancient to modern. In the $17^{\text {th }}$ century, the Malay language could be considered as modern linguistically. In this modern phase, the Malay language started to borrow languages from Arabic language (Collins, 2005, p. 40) and the borrowing other languages tradition still continues nowadays, as it still occurs in the Indonesian language. From the history presented in the background, it is clear that the Malay language is a derivation of the ancient Austronesian language and survives from language extinctions for hundred years thanks to its adaptability.

As it is told by Collins (2005, p. 4-5), Malay itself believed by the experts formed from the area of West Kalimantan due to a lot of evidence that led to that belief. It has been said in the beginning; the people of the island of Formosa who migrated through the Philippines and to the West are now settled in the islands of Southeast Asia. They migrated in two waves, the first wave headed west and the second headed east.

On the first wave, they settled in West Kalimantan approximately 2.000.000 years ago. These ancient Malay language speakers inhabited ecologically special areas, the area of the marshes, wet soil, delta, and the coastal area of the river system in West Kalimantan. This settlement pattern allowed them to maintain and develop shipping technology. The techniques of their sailing began to be more advanced so that they finally set out to relocate their habitation approximately $100 \mathrm{CE}$ to the west and the south. Heading west, they crossed the South China Sea through Tambela and Riau Islands to Sumatra and headed toward the southern tip of Asia today known as Malaysian Peninsula.

From the west, they spread clockwise on the northern coast of Kalimantan and then to the south, all the way back to the west. Therefore, most regions in Kalimantan aquatic systems have habitation with native speakers of Malay in various dialects. From the center coast on East Kalimantan, they established habitation on the southwest island of Luzon is now known as 
Manila Bay, then further eastward to the Maluku Islands. Their migration also happened to the south across the Karimata strait toward Bangka Belitung and in the southern Sumatra (Musi River area) and the west coast of Java.

Marsono (2013, p. 8-9) also agrees with Collins idea of Malay language timeline history. In the $7^{\text {th }}$ century of CE, ancient Malay language was used throughout the Kingdom of Sriwijaya in Palembang, South Sumatra, and it also was the official language. Evidence which can be found on the island of Sumatra were the inscription of Kedukan Bukit (683 CE), Talang Tuwo (684 CE), Telaga Batu (Without Year), Kota Kapur (Without Year), Bangka (686 CE), and Karang Brahi $\left(686 \mathrm{CE}\right.$ ). Malay was also used in the $13^{\text {th }}$ century to spread Islam in Indonesia. From Ancient Malay language, its evolution began in the $14^{\text {th }}-16^{\text {th }}$ century and used as a lingua franca in the trading community in Indonesia. Local merchants, Indian, Chinese, Persian, Arabic, and others used Malay when they were making transactions. Then in the late of $16^{\text {th }}$ century, European nations such as Portugal, England, Netherland, and Spain, in searched for spices, came to Indonesia, and of course, the first initial language used to communicate was Malay.

These were some of the reviews on the previous studies related to this research. Poedjosoedarmo (2004) discusses language acquisition that is done by individual and society. In his research, it was said that development of language acquisition among children, a non-standard dialect into a standard one, and a pidgin into creole developed in a similar way, from a simple stage into a complex and efficient one. In this case, he took the development of grammatical principles. He concluded that grammar and language could grow optimally only when there was enough linguistics exposure in the environment which would serve as the input for acquisition and enough encouragement which would serve as the motivator for learning. This conclusion also could be referred to the development of pidgin and creole. Children developed creole because they found themselves born into a multilingual community in which the language for peer communication was a pidgin.

Another researcher also talked about Indonesian language acquisition. Fauzi (2012) in his writing talks about children's Indonesian language acquisition in wh-questions. He found that the children started to acquire whwords such as siapa, apa, mana, ngapain, but the major wh-questions that were frequently used was apa (what). Bagaimana (how come) appeared to be delayed in their acquisition and to anticipate that, they used other productive low question words kok and ngapain. The last findings in his research were the position of wh-questions siapa (who) and mana (where) was put in an initial position, whereas apa (what) was used as the opposite way. 
Indriati (2014) seemed to have a high concern about the existence of local language, especially Dayaknese in Central Kalimantan, that might be endangered because of the increasing use of Indonesian language. There were many reasons to this problem, migration of people who do not have the same local language, cross-cultural marriage, and also school environment. It is found that most Junior high school students in the research used Indonesian because it is the main tool for interaction in the school environment. However, it is not possible to preserve the local language since it became a compulsory subject in school.

From those previous studies, it is clear that the Indonesian language is widely used in Indonesia as the national language. Every individual and society use it to communicate if they do not have the same mother tongue. It also has a grammatical complexity that children need to develop as they need more exposure in order to acquire this language better. It is true that Indonesia becomes the first language of most children nowadays because of cross-cultural marriage and school environment. Parents who have different mother tongue tend to use Indonesian to communicate with their children at home. Meanwhile at school, Indonesian is one of the compulsory subjects and teachers are asked to use Indonesian in classes.

Indonesian is said to be a modern Malay language. Throughout its history, the Indonesian language has absorbed a lot of foreign vocabularies such as Sanskrit, Arabic, English, Dutch, and much more. However, the origin of Indonesian is modern Malay. As described in the background, Indonesian language was derived from Malay language yet it borrows foreign language units from other languages, even from outside its own family language. In addition, it also becomes the national language even before Indonesian independence. This language phenomenon led to the idea of pidgin and creole where there were language contacts between local and foreign people that happened in Indonesia and it more or less gave influence to the original language of local people, in this case, Malay language. This influenced language, Malay, then became the first language of most speakers in Indonesia, and then in 1928 its status was established as the national language and the name was also changed to the Indonesian language. It is why the Indonesian language is questionable whether its existence is pidgin or creole.

The purpose of this research was to prove whether the Indonesian was a pidgin, creole, or a pidgin that authorized into a creole.

The result of this study was intended to give the clearer status of Indonesian language and to give a contribution to literature study about Indonesian language and Malay language. It will be based on literature study about pidgin and creole and compared to the characteristics features contained 
in the Indonesian language so that later it could be deduced whether the Indonesian language was regarded as pidgin, creole, or neither of them.

\section{METHOD}

To explain the problem of the study that was mentioned in the background, a certain kind of research method must have been chosen appropriately. Zed (2008, p. 3) says “...riset kepustakaan atau sering juga disebut studi pustaka, ialah serangkaian kegiatan yang berkenaan dengan metode pengumpulan data, membaca, dan mencatat serta mengolah bahan penelitian". This research was called library research which was a sequence of activity regarding the data collection, reading, and taking notes, as well as processing the research data. It was conducted by collecting the data resources related to the research, such as book references and journals, reading the collected materials as well as taking important notes from them, and processing the data collection to have a proper deduction of the problem.

Teitelbaum (1994, p. 3) states that there are two categories of research, library and experimental. He also adds that library research was one in which no experimental design was set up, where information was obtained primarily from a search of written materials. This kind of research was conducted by preparing books, articles, theses, and dissertations, though it would focus on primary sources and it also required a thorough search of all sources that might exist dealing with the chosen topic, in this case, pidgin and creole.

Having related to Zed's (2008) opinion about library research's steps, it was not exaggerating that Teitelbaum says the task of the researcher was to become a sleuth who tracked down any and all leads. The researcher needed to find and collect any possible written materials, filter the information related to the chosen topic thoroughly, analyze the data collection, and draw a conclusion from the analysis.

The subject of this study was the Indonesian language that was considered as modern Malay language nowadays. Library research was a kind of research suitable for field data retrieval which was difficult to do, in this case, the data could not be taken from the field because the beginning of the problem happened hundred years ago. The first thing to do was to collect the research related to Indonesian and Malay language relationship and also pidgin and creole from book references and journals. All the resources were restricted from 1986 up to 2016.

The references used for this research were mainly taken from Collins (2005) and Poedjosoedarmo (2004). After all the materials needed was collected, everything must have been read thoroughly. It was very important for taking notes to gather the valuable information found in the literature. The latter step 
was to process the data and then it was drawn into conclusions on the problem that has been determined in the introduction.

\section{FINDINGS}

Collins (1986, p. 1) states that since the appearance of Schuhardt' multivolume work (1883-1891), linguists have studied languages generally described as contact languages. As for pidgin and creole themselves, Collins (1986, p. 1) says that they had markedly increased in the last three decades partly because of the serious sociolinguistic problems faced by the new multiethnic nations of Africa, Oceania, Asia, and the Carribean and partly because of the interesting problems which this group of languages poses to the rapidly multiplying schools of linguistic theory. Hence, after 1891, pidgin and creole study had just become popular because the problems had just been identified in some areas in the world and also the rapidly multiplying establishment of schools of linguistics increased the interest of scholar about these matters.

On the other hand, Knapik (2009, p. 1) says that the study of pidgin and creole phenomena has long been neglected in linguistics. It was due to its stereotype that they were often considered as slave talk or uneducated language since most of the pidgins and creoles were created in the place where slave and inhabitant met. Thus, it was no wonder that the language was considered as low prestige.

Chaudenson cited by Knapik (2009, p. 2) also mentions that there were two types of pidgin and creole, which were endogeneous and exogeneous. The first type, endogenous, was pidgins and creole that had developed from contact between an indigenous population and immigrant group; in the context of colonial expansion, this was the case of a colony based on trading posts and centers. The colony of Dutch had been in Indonesia for about 300 years. Not to mention that other countries such as China, Arab, India which came even long before the Dutch, came as an immigrant to Indonesia as traders, also settled in. Language contact could not be avoided. Each language must have borrowed others in order to communicate well, and for some vocabularies that might have not any equivalent in the Malay language, there was no other choice besides borrowing the words.

The second type was exogenous which had developed out of contacts that among immigrants and the transplanted population. This type was impossible to consider since the Indonesian language had made a lot of contact with other languages. Thus, this type was not applicable.

Literature review on pidgin and creole was very important to determine whether the Indonesian language can be classified into a pidgin or a creole. 
First of all, it is important to find a definition, characteristics, rules, and how the process of pidgin and creole, so it could be called as it is.

\section{Language Contact}

O'Grady and Dobrovolsky (1993, p. 272) define “... language contact, which occurs when speakers of one language frequently interact with the speakers of another language or dialect." Language contact may happen when a speaker forms a language frequently interacted with other languages or other dialects. In this case, language contact has happened a lot even before Indonesian language's establishment. These languages came from different family languages or same family language and more or less it brought changing to either or both languages that made contact.

It explained the conditions of a language contact as it may have happened if there were at least two languages which made contact and those languages were used respectively and alternatively by the speakers. This interaction was called language contact and the evidence of it could be seen in the speakers themselves because they were the place to store the language contact.

\section{Pidgin}

Todd (1990, p. 1) says that "A pidgin is a marginal language which arises to fulfill certain restricted communication needs among people who have no common language". He believes that a pidgin is a marginal language that appears to fill certain limited purposes of communication among the people who do not speak each other language. Holmes (1992, p. 90), on the other hand, defines "a pidgin is a language which has no native speakers". Holmes, who is an expert of Sociolinguistics, says that a pidgin is a language spoken by the people who already got their mother tongue. It is true that pidgin was created only for some quick communication purposes, so both parties must have their own mother tongue.

In addition, Holm (2000, p. 5) has the same notion as two other that he states that a pidgin is a reduced language that results from extended contact between groups of people with no language in common; it evolves when they need some means of verbal communication, perhaps for trade, but no group learns the native language of any other group for social reasons that may include lack of trust or of close contact. Nobody speaks their native language since it might bring the social issue among the speakers, but on the other hand, the communication must be maintained so that they create another way to avoid it. 
From the three definitions mentioned by experts above, it can be concluded that a pidgin is a mixed language used in a certain situation and purpose where people have no common language to interact with each other.

\section{Creole}

Todd (1990, p. 1) says "a creole arises when a pidgin becomes the mother tongue of a speech community". According to him, a creole is created when a pidgin becomes the mother tongue of a community of language users. Meanwhile, Holmes (1992, p. 90) states that "A creole is a pidgin which has acquired native speakers". According to her, creole is a pidgin that has gained first people who speak the language as their mother tongue. She also gives further explanation "a creole is a pidgin which has expanded in structure and vocabulary to express the range of meanings and serve the range functions required of a first language." When a pidgin survived, it must have collected more vocabularies and increased its structure complexity, so that it could not be only used in one domain, but also in many ranges of the domain. This led to its development to become the first language of the children who found and spoke the language.

Holm (2000, p. 6) has added more opinion about creole that it has a jargon or a pidgin as its ancestry: it is spoken natively by an entire speech community, often one whose ancestors were displaced geographically so that their ties with the original language and sociocultural identity were partly broken. It is believed that a creole was originally a pidgin then its status changed into creole when it is finally spoken by a group of people as their first language. It affects not only the original language itself but also the sociocultural identity. The mix of languages means that the speakers need to justify their sociocultural life. It may not affect the pidgin users as they will not have identity issues, but the problem might arise with the descendants who were exposed to diversity.

From that explanation, it can be deduced that a creole that emerged from a pidgin used by a group of people whose descendants have used the language and made it their mother tongue in everyday life. Even though the roots of the language was known, the language develops more complex language units, for instance, it develops phonological developments in its sound system or even higher units.

\section{Characteristic Features of Pidgin and Creole}

According to Holmes (1992, p. 94), characteristic features of pidgin were as follows. First, pidgin was used for restricted domains and functions. Holmes (1992, p. 92) says that an average monolingual adult had about 25,000-30,000 
words, whereas a pidgin only had a few hundred words in a domain, for instance, a pidgin that used for trading. It meant that a pidgin only had a small amount of vocabulary. Unless it was developed, it likewise would disappear once the function or the domain disappeared. For example, if the trading grew successful, it could last longer and the descendants learned the language. In other words, a pidgin survived and it acquired its first speakers, then that meant it changed into a creole. However, if the trade was unsuccessful, then the language died out. There was also one more alternative. When a trade grew, the language contact increased as well. This could lead to at least one side learning the other's language, and then a pidgin was no longer needed.

The second characteristic was that it had a simplified structure compared to the source languages. The original language had already developed and regular structure in grammar. This language somehow appeared incomplete. Pidgin borrowed the structured grammar of the source language, but it tended to reduce the grammatical signal to a minimum. For the speaker, it was apparently easy to learn and use the language. However, it might be difficult for a listener of pidgin to fully understand the language due to the reduction and its structural irregularities.

In general, pidgin was considered a low-prestige and attracted negative attitude, especially from outsiders. The listener might have the same reaction when they heard a pidgin; they would think it was a silly language. It sounded a lot like a baby-talk, meanwhile, the speaker did not think as it was. This was the third characteristic of a pidgin language.

There were 3 characteristic features of creole (Holmes, 1992). First, creole had been learned by children as the first language. As the time went by, the language broadened its language units and acquired more speakers. This was the indication of early creole language.

The second characteristic was shown when a creole had more regular structured grammar and rich in vocabulary. It could be said that the more the speakers, the more the needs of broadening the language in order to communicate better and maintain the existence of the language. Creole occurred to experience many revisions in its grammatical; it appeared to be more regular than pidgin. The vocabulary was not only restricted to in trading or agriculture but also other aspects of life, such as law, education, medicine, etc.

The last was the status of creole which differed from pidgin. The attitude expressed towards a creole was different from the one towards pidgin. It appeared less low prestige than pidgin did. Of course, it was according to the speakers or the community who used the language. Some still thought that creole was no less than a pidgin even though it had broader development. For 
example, Tok Pisin language in Papua New Guinea, they considered this language had high status and prestige and also the language of solidarity. However, other people who did not speak this language might find this language funny or silly.

Another example of creole was considered a silly language could be seen from Hall cited by Todd (1990, p. 26) that as recently as 1953 Neo-Melanesian was referred to as 'inferiority made half articulate' and its grammar was attacked as being 'crude and incredibly tortuous'. Todd (1990, p. 26) did not decline the statement, but he did not fully agree with that as well as he states,

To insist that such statements are unscientific, inaccurate, linguistically untenable, subjective and prejudiced does not alter the fact that, until very recently, pidgin and creole speakers have been made to feel ashamed of the language in which they could most easily express themselves.

However, in some countries as Papua New Guinea and Haiti, their creoles were considered prestigious. In Haiti, it was considered as the language of honesty, truth, and sincerity (Todd, 1990, p. 26). Furthermore, he adds that although it would be inaccurate to suggest that the sense of shame and inferiority which creole speakers felt has disappeared entirely, the evidence clearly shows that it was disappearing. It meant that to creole had become a prestigious language in some countries but it still left a trace of silliness and low prestige.

\section{The Development Process of Pidgin to Creole}

According to Todd (1990, p. 51), there are four phases in which a pidgin could turn into a creole. The phases were as follows.

Phase 1 was the phase that involves casual contact and unsustainable between the migrants and the local people. From these contacts, a marginal pidgin evolved and they could communicate with the help of gestures and communicate about the purposes, figures, trade rules, and others.

Phase 2 was the phase which had started when pidgin was used by and among the local people. At this stage, pidgin could be expanded in only one way, which was from language users' mother tongues. This phase helped to explain the original lexical items and a lot of direct translation which were found in all the pidgin and creole.

When interracial contact increased, phase 3 occurred. At this time, the vocabulary was expanded by borrowing lexical items of "dominant" language.

Phase 4 was limited to the area where a language continued to be a nationwide official language. When contact between the national official language and a pidgin or creole continued, and education of national official 
language became widespread, the process of creolization occurred. Pidgin or creole became more influenced by the standard language in terms of phonology, lexicon, and syntax.

\section{DISCUSSION}

Malay is derived from Austronesian language family which came from West Kalimantan and initiated a culture and created a language called Malay. From West Kalimantan, the language was widespread.

The Indonesian language might reflect a hint of pidgin or creole due to its contact with other languages, and it borrows a number of their language units too, especially in the area of phonology, morphology, and vocabulary. According to Crowley (1992, p. 262), "when speakers of several different languages come into contact in a situation where there is an urgent need to communicate and there is little social opportunity to learn whatever happens to be the dominant language, and where no other language predominates in terms of numbers of speakers, what often happens is that a pidgin language develops." Indonesia is known for its language diversity. Even though the Malay language is known widely, it might not be the mother tongue of some ethnics. Besides, its contact with other foreign languages such as Arabic, English, Dutch, etc. in the beginning of its modernization made it absorb more language units as in sound and word. It was a situation where Crowley mentions in his statement.

There were two Malay languages which were used in Indonesia, the Malay language used in the kingdom to spread Islam and the one used for trading. The language used by the Malay kingdoms was known as high Malay, while the low Malay language spoken in the trade was a mixture of other languages such as Arabic, Chinese, Dutch, English, Portuguese, and others. Of course, this contributed to what is called Indonesian language today. Contact between local people with foreign traders made assumptions whether the Malay language is pidgin and Indonesian is creole of the Malay language. It is presumable because there has been lexicon mixture between local language and languages brought by foreign traders who made interaction with the local people.

The idea of High and Low Malay was supported by some experts. Poedjosoedarmo (2002, p. 17) mentions that some people called the variety taught in schools at the beginning of the $12^{\text {th }}$ century Melayu Tinggi (high Malay). This variety was not only taught in school but also used on official occasions by members of the royal courts in Malay sultanates. In Indonesia, Islamic kingdom in the past had been very successful in spreading Islam; therefore they needed a language that was appropriate to do so. Thus, there 
might be a high possibility that the Indonesian language was derived from high Malay used by the royals to spread Islam.

On the other hand, Collins (1986, p. 196) states that the term of low Malay was used in 1770 when a person named Parkinson took notes of vocabularies used in Batavia or Jakarta nowadays. Low Malay might have been considered as Malay that used by the local or foreign people as trading language as that time Batavia was one of the most influential harbor trading centers.

In fact, the Indonesian is neither a pidgin nor creole. As noted in the introduction, it is true that Indonesian was descended from modern Malay language. However, Malay language which became the beginning of Indonesian was high Malay or Malay used by the kingdom and those who spread Islam. Malay was an original language and not a language mixture of different languages for trading purposes only. Malay which was used as a lingua franca appeared to be different from high Malay spoken by the royals.

Having judged from the characteristics features of a pidgin, Malay language could not categorize as a pidgin. The first feature was a pidgin language used for limited functions and domains, while the Malay language had already had a vast function and domain, not a certain aspect only. These function and domain could be exemplified as trading purposes between the local people and foreign traders, whereas that time Malay language was not only used as trading lingua franca but may have also extended to the domain of agriculture, fishing, hunting, and others. This was because of the first inhabited place, West Kalimantan, had ecology areas such as peatland, swamp, wet soil, delta, and coast.

The second characteristic was pidgin has a simplified structure and a small amount of vocabulary compared to the original language. Malay was an original language, and Indonesian nowadays has unique language units' complexity. The existing structure was already complex, both in terms of the regularity of the sound of phonological, various kinds of morphological processes, and the structured syntax system. If it was seen in terms of vocabulary, Malay also had developed quite a lot of vocabulary.

However, it was possible to increase the number of vocabularies since it was not an obstacle to keep absorbing vocabulary from languages brought by foreign people, rather it added to the diversity of vocabulary in Indonesian. The equivalent may be found easily instead of using the direct vocabulary of the certain language. The evidence of Indonesian language that has continuously increased its vocabulary can be found in Kamus Besar Bahasa Indonesia (KBBI) that contained entries of modified foreign vocabulary. 
Adelaar (1985) thinks that there were three stages of loaning words in the Malay language. The first was the process of borrowing other languages into Malay, then the process of borrowing Malay into another language, and the process of borrowing each other's language.

Modified vocabularies were also found in the phonological system. Indonesian tends to delete or change a certain sound in order to make it easy to pronounce. It also uses most letters which represent symbols in the phonological system for its orthographical system. For instance, the English word "coordination" is absorbed into Indonesian and becomes "koordinasi". The letter " $c$ " in English was changed into " $k$ " as it is pronounced in Indonesian. As for sound changing, kəø0:dineIJn/in English was modified into koordinasi/ which has been simplified into sounds available in Indonesian without changing the meaning.

In addition, Poedjosoedarmo $(2002, \mathrm{p} .15)$ considers this as a benefit that he says "the influx of loanwords and newly created words has made the Indonesian phonemic system richer as well." Indonesian language also absorbed new consonant phonemes such as $|\mathbb{L} /,| \mathrm{J} / \mathrm{K} / \mathrm{x} /$, and $/ \mathrm{z} /$. These consonants were known to be borrowed from Arabic sounds and could be found in words as filosofi filosofi/, syarat/Jarat/, makhluk/maxluk/, and zaitun zaitun/.

The last characteristic was that pidgin was considered a low-prestige and also a silly language. This did not apply in the Malay language since Malay was also spoken by the royals and people who spread Islam. This notion was supported by Poedjosoedarmo (2002, p. 17) as he states that High Malay was a variety of Malay which was found in documents such as royal genealogies, the laws of certain sultanates, and legends and it was some kind of literary language. For such important affairs, the range of vocabulary might be vast, whereas, for pidgin, the vocabulary was limited to certain use. Therefore, it may not be possible to consider it as low prestige or silly language.

As for the characteristic of creole, it is true that the Indonesian language appeared to have broader function and domain and it also had more structured grammar and rich in vocabulary. However, Malay had already had function and domain not only in trading, but also applied to other domain such as sailing, fishing, planting, and more. It had already developed complex syntax. As it is known that most of the language that had contact with Malay came from another family language, such as Dutch and English. However, it still maintained its syntactic structures of Austronesian language and was not affected by other languages' structure. As it is said before, Malay had various domains that it had already developed various vocabularies in the first place. 
Malay, at the colonialism era in Indonesia, was the most spoken language in Indonesia. At the time of colonization, the Dutch language had also become an important language. However, Dutch was considered to have a high prestige and not everyone could learn it. It was limited to certain community, like the royals or priyayis. That was the reason why the Malay language does not lose its existence in the association of Indonesian people even though there were many ethnic languages in each respective region.

On the other hand, Malay was used as a mean to fight against the colonialism and became one of Indonesia's national symbols instead. Malay was taught in schools for the army and police, engineers, health workers, carpenters, school teachers, agricultural workers, government officials, and members of Protestant priests and evangelist team (Collins, 2005, p. 88).

On October $28^{\text {th }}, 1928$, the youth of Indonesia swore a pledge which was known as Sumpah Pemuda. The third line "Kami, putra putri Indonesia, menjunjung tinggi bahasa persatuan Bahasa Indonesia" means that the youth considered language as one of the very important things in achieving independence. Along with the pledge, Indonesian language was known as the national language of Indonesia and no longer called the Malay language, although basically Indonesian language was Malay. Speakers were also no longer referred as the "original", "native" or "inlander", but an Indonesian who is one race, one nation, and one language. In the past, Malay was considered as the language of commerce and a mean to spread religions in Indonesia, and then in the $20^{\text {th }}$ century, Malay lifestyle was associated with modern, welleducated, and the intention for autonomy (Collins, 2005, p. 88). Therefore, Indonesian language became a mean to achieve independence and later renamed as Indonesian and a symbol of modern nationalism to the people of Indonesia.

The Indonesian language also kept increasing vocabularies in order to enrich its equivalent to other languages. This notion was emphasized by Poedjosoedarmo (2002, p. 14) that Indonesia has become richer particularly in terms of its lexicon and phonology. The lexicons had already talked about computer technology, multinational enterprises, civil law, politics and diplomacy, military and defense, public administration, secondary and tertiary education, public works, health and medicine, dentistry and animal husbandry, sports and entertainment, the environment and pollution, zoology and botany, psychology and psychiatry, insurance and banking, agronomy and the food industry, civil engineering and architecture, nuclear science and physics, mining and geology, forestry and the mechanization of farming, hydrology and water reservoirs, volcanology, library science and documentation, aeronautics 
and flight engineering, etc. With these amounts of domain range, it meant that in the future KBBI might be revised continuously as the entries kept increasing.

\section{CONCLUSION}

This library research about the Indonesian language came into a result where it was neither pidgin nor creole. No characteristics of pidgin or creole were found in this language. Indonesian or Bahasa was High Malay that was used as a mean to achieve independence. Indonesian was a symbol of modern nationalism to the people of Indonesia. One of early modernization marks of Malay was borrowing other language's units, and it still continues nowadays in the Indonesian language. It is possible that Indonesian will continue to absorb the language units of other foreign languages, such as sounds, lexicons, or even grammar and it makes the Indonesian language even richer.

\section{REFERENCES}

Adelaar, K. A. (1985). Proto-malayic: The reconstruction of its phonology and parts of its lexicon and morphology. Alblasserdam: Kanters.

Collins, J. T. (1986). Antologi kajian dialek melayu. Kuala Lumpur: Dewan Bahasa dan Pustaka, Kementerian Pelajaran Malaysia.

Collins, J. T. (2005). Bahasa melayu bahasa dunia: Sejarah singkat. Translated by Alma Evita Almanar. Jakarta: Yayasan Obor Indonesia.

Crowley, T. (1992). An introduction to historical linguistics. Auckland: Oxford University Press.

Fauzi, I. (2012). The acquisition of wh-questions: A simple case in Indonesian children. Journal on English as a Foreign Language, 2(1), 1-10.

Holm, J. A. (2000). An introduction to pidgin and creoles. Cambridge: Cambridge University Press.

Holmes, J. (1992). Learning about language: An introduction of sociolinguistics. New York: Longman Publishing

Indriati, I. (2014). Do you care your local language? Journal on English as a Foreign Language, 4(2), 55-62.

Knapik, A. (2010). On the origins of pidgin and creole languages: An outline. Styles of Communication,1(1), 1-5.

O'Grady, W., \& Dobrovolsky, M. (1993). Contemporary Linguistic Analysis: An Introduction. Ontario: Copp Clark Pitman Ltd.

Poedjosoedarmo, S. (2002). The behavior of languages used in a bilingual society: The case of Javanese and Indonesian in Java. Phenomena Journal of Language and Literature, 1(6), 1-21.

Poedjosoedarmo, S. (2004). Language development and grammatical principles. Kajian Linguistik dan Sastra, 31(16), 80-88. 
Teitelbaum, H. (1994). How to write a thesis (3 ${ }^{\text {rd }}$ Ed.). New York: Arco.

Todd, L. (1990). Pidgins and creoles ( $2^{\text {nd }}$ Ed.). London and Boston: Routledge \& Kegan Paul Ltd.

Zed, M. (2008). Metode penelitian kepustakaan. Jakarta: Yayasan Obor Indonesia.

\section{Author's Brief CV}

Dellis Pratika was born in Palangka Raya, 29 August 1990. She finished her undergraduate program at English Education Study Program (S.Pd.), Universitas Palangka Raya (UPR) in 2012 and her master at Linguistics Study Program (M.A.), Universitas Gadjah Mada (UGM) in 2014. She is currently working at IAIN (State Islamic Institute) Palangka Raya as Dosen Luar Biasa (DLB) in English Education Department. 
